\title{
Edukasi tentang Protokol Pencegahan Covid-19 kepada Masyarakat Kelurahan Lebak Bandung Kota Jambi
}

\author{
Fithriyani $^{1}$, Marnila Yesni ${ }^{2}$ \\ ${ }^{1,2}$ Program Studi S1 Keperawatan, STIKes Baiturahim Jambi \\ Email: fithri.yani25@yahoo.co.id
}

Submitted : 26/04/2021

Accepted: 14/06/2021

Published: 28/06/2021

\begin{abstract}
The number of Covid 19 cases is increasing and cannot be ignored considering the increase every day continues to increase. The impact of the Covid 19 pandemic has an impact on various fields, especially the economy. To avoid the increasing number of sufferers, the government limits activities that cause crowds, maintains distance and maintains hygenicity in the community in carrying out daily activities known as health protocol regulations. The behavior and actions of the community must change completely from the usual actions that are often carried out, for that it is necessary to have socialization on how to prevent the transmission of Covid 19 by implementing the health protocol that has been advised by the government. The purpose of this community service activity is to remind and help public understanding of the implementation of health protocols during the Covid 19 pandemic. The form of activities is in the form of counseling, giving hand sanitizers and masks. Lack of public awareness and knowledge about Covid-19 can be overcome by providing knowledge, through socialization about the importance of implementing this activity protocol in order to help people face New normal conditions, by helping people live by complying with health protocols. The results of the activity obtained the enthusiasm of the residents in following the activity until the end with the many questions asked. Suggestions for the Lebak Bandung Village to hold outreach activities about the prevention of Covid 19 in their environment because there are still many residents who do not understand about prevention which is only done.

Keywords: Covid-19, education, health protocol
\end{abstract}

\begin{abstract}
Abstrak
Angka kasus covid 19 semakin meningkat dan tidak bisa diabaikan mengingat pertambahan setiap harinya terus bertambah. Dampak dari pandemi covid 19 ini berpengaruh di berbagai bidang terutama perekonomian. Untuk menghindari angka penderita yang terus meningkat, maka pemerintah memberikan pembatasaan kegiatan yang menimbulkan keramaian, menjaga jarak dan menjaga hygenitas pada masyarakat dalam melakukan kegiatan sehari-hari yang dikenal dengan peraturan protokol kesehatan. Perilaku dan tindakan masyarakat harus berubah total dari tindakan biasa yang sering di lakukan, untuk itu perlu adanya sosialisasi tentang bagaimana mencegah penularan covid 19 dengan menjalankan protocol kesehatan yang sudah di himbau oleh pemerintah. Tujuan kegiatan pengabdian masyarakat ini adalah untuk mengingatkan dan membantu pemahaman masyarakat tentang pelaksanaan protokol kesehatan selama pendemi covid 19. Bentuk kegiatan berupa penyuluhan ,pemberian hand sanitaser dan masker. Kurangnya kesadaran dan pengetahuan masyarakat tentang Covid-19 dapat diatasi dengan memberikan pengetahuan, melalui sosialisasi tentang pentingnya melaksanakan protokol Kegiatan ini dalam rangka membantu masyarakat menghadapi kondisi New normal, dengan membantu masyarakat hidup dengan menaati protokol kesehatan. Hasil kegiatan didapatkan antusiasme warga mengikuti kegiatan sampai akhir dengan banyaknya pertanyaan yang disampaikan. Saran bagi kelurahan lebak bandung mengadakan kegiatan sosialisasi tentang pencegahan covid 19 dilingkungannya karena masih banyaknya warga yang belum memahami tentang pencegahan yang hanya dilakukan.
\end{abstract}

Kata Kunci : Covid-19, edukasi, protocol kesehatan 


\section{PENDAHULUAN}

Corona Virus atau dikenal dengan COVID-19 saat ini telah menyebar ke berbagai negara didunia. WHO (World Health Organisation) telah menyatakan COVID-19 merupakan Kegawat daruratan Global atau pandemic pada 11 Maret 2020 (Djalante, et al., 2020). COVID-19 dilaporkan cukup menular dengan tingkat kematian yang relative tinggi dan dilaporkan terus meningkat.

Indonesia adalah negara terpadat keempat di dunia, dengan demikian diperkirakan akan sangat menderita dengan adanya pandemic COVID-19. Pandemi Covid-19 khususnya diIndonesia terus meningkat setiap bulannya. Kasus positif covid di Indonesi September 2020 ini sudah mencapai 291.000 kasus, 218.000 sembuh dan 10.856 meninggal dunia dan di provinsi Jambi 543 kasus, 268 sembuh dan 11 orang meninggal dunia. Angka tersebut tidak bisa diabaikan mengingat pertambahan setiap harinya terus bertambah (Gugus Tugas COVID 19, 2020)

Dampak dari pandemi covid 19 ini berpengaruh di berbagai bidang terutama perekonomian. Pemerintah akhirnya mengeluarkan peraturan tatanan kehidupan baru atau disebut dengan New Normal. Tatanan kehidupan baru atau kenormalan baru diberlakukan mengingat kesulitan ekonomi dan pendapatan masyarakat di masa pandemi ini. Untuk menghindari angka penderita yang terus meningkat, maka pemerintah memberikan pembatasaan kegiatan yang menimbulkan keramaian, menjaga jarak dan menjaga hygenitas pada masyarakat dalam melakukan kegiatan sehari-hari yang dikenal dengan peraturan protokol kesehatan. Perilaku dan tindakan masyarakat harus berubah total dari tindakan biasa yang sering di lakukan. Sudah banyak himbauan dari pemerintah terkait perubahan prilaku yang harus dilakukan, namun nampaknya tidak mempengaruhi semua orang secara merata.
Pandemi Covid-19 ini masih akan berlangsung selama beberapa waktu ke depan, sehingga mau tidak mau masyarakat perlu menyesuaikan diri untuk hidup berdasarkan protokol kesehatan yang ditetapkan demi mencegah penularan Covid-19. Kurangnya kesadaran dan pengetahuan masyarakat tentang Covid-19 dapat diatasi dengan memberikan pengetahuan, melalui sosialisasi tentang pentingnya melaksanakan protokol. Kegiatan ini dalam rangka membantu masyarakat menghadapi kondisi New normal, dengan membantu masyarakat hidup dengan menaati protokol kesehatan, antara lain Menggunakan alat pelindung diri berupa masker, Membersihkan tangan secara teratur dengan cuci tangan pakai sabun dengan air mengalir atau menggunakan cairan antiseptic, Menjaga jarak minimal 1 meter dengan orang lain, Meningkatkan daya tahan tubuh dengan menerapkan Perilaku Hidup Bersih dan Sehat. (Kemenkes, 2020).

Masyarakat kelurahan lebak bandung berada di pusat kota dan berdekatan dengan rumah sakit yang rentan tertular covid 19 . Hasil observasi masihbanyak masyarakat yang tidak menggunakan masker,tidak menjaga jarak di yempat keramaian dan hanya sedikit yang mencuci tangan di tempat umum. Berdasarkan wawancara masyarakat menyatakan masih bingung tentang pencegahan covid 19 dan isu yang beredar di kalangan masyarakat terkait covid19 yang salah persepsi.. Berdasarkan kondisi tersebut kami dosen STIKes Baiturahim Jambi berfikiran perlunya melaksanakan kegiatan pengabdian kepada Masyarakat terkait dengan pencegahan Covid-19 melalui edukasi tentang protokol pencegahan Covid-19 di lingkungan kelurahan Lebak bandung yang juga termasuk lingkungan STIKEs Baiturahim Jambi. 


\section{TARGET DAN LUARAN}

Target kegiatan ini yaitu dengan memberikan pengetahuan, melalui sosialisasi tentang pentingnya melaksanakan protokol kesehatan selama pandemic covid 19.

Luaran kegiatan ini meningkatkan pengetahuan tentang protokol kesehatan selama pendemi covid 19, Pembagian hand sanitizer dan masker

\section{METODE PELAKSANAAN}

Kegiatan pengabdian masyarakat ini dilaksanakan pada Sabtu, 13 Februari 2021 pukul 11.00-12.00 WIB di Posbindu kelurahan lebak bandung Kota Jambi. Sasaran kegiatan adalah warga RT 32 Kelurahan Lebak Bandung. Bentuk kegiatan berupa Sosialisasi tentang protokol kesehatan selama pendemi covid 19 dan pembagian hand sanitizer dan masker.

\section{HASIL DAN PEMBAHASAN}

Kegiatan pengabdian masyarakat dengan tema "Edukasi tentang protokol kesehatan pada warga RT 32 Kelurahan Lebak Bandung Kota Jambi telah terlaksana pada hari Sabtu, 13 Februari 2021 pukul 11.00-12.00 WIB. Peserta kegiatan pengabdian masyarakat ini dihadari oleh 17 orang, dan tim kegiatan yang terdiri dari 2 orang dosen dan 2 orang mahasiswr Tempat pelaksanaan dilakukan di Posbind RT 32 kelurahan lebak bandung Ko1 Jambi.

Kegiatan dimulai dengan melakuka pemberian masker dan hand sinitis kepada warga sebelum memasuki posbind ,kemudian warga diminta mengisi absen: peserta. Setelah warga berkump kemudian dilakukan sosialisasi tentan protokol kesehatan menghadapi mas pandemi covid 19 yang terdiri da. penjelasan tentang 4 cara pencegahan terhadap covid 19 yaitu menggunakan masker, menjaga jarak lebih dari 1 meter, sering mencuci tangan dengan sabun/antiseptik, menjaga pola hidup sehat.
Media yang digunakan berupa poster dan leaflet. Peserta mendengarkan materi yang disampaikan lalu dilakukan tanya jawab. Secara keseluruhan, kegiatan berjalan dengan lancar serta antusiasme dari peserta juga sangat baik. Pada saat penyampaian materi, peserta sudah cukup paham terkait dengan materi yang diberikan. Hal ini dapat dilihat dari jawaban dari pertanyaan evaluasi yang diberikan moderator kepada peserta. Kegiatan semacam ini masih dibutuhkan oleh peserta dengan materi yang menyesuaikan dengan permasalahan yang dialami di Kelurahan lebak bandung sebagai upaya pencegahan penularan covid 19 yang sudah berjalan satu tahun terakhir.

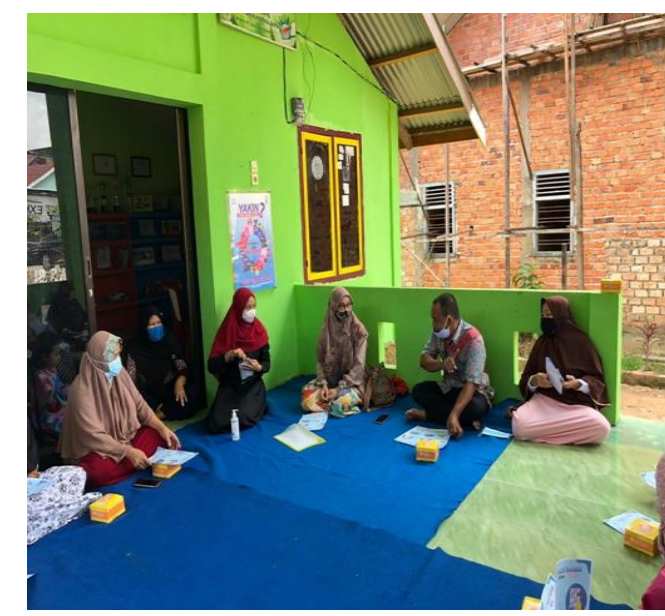

Gambar1. Edukasi Protocol Kesehatan

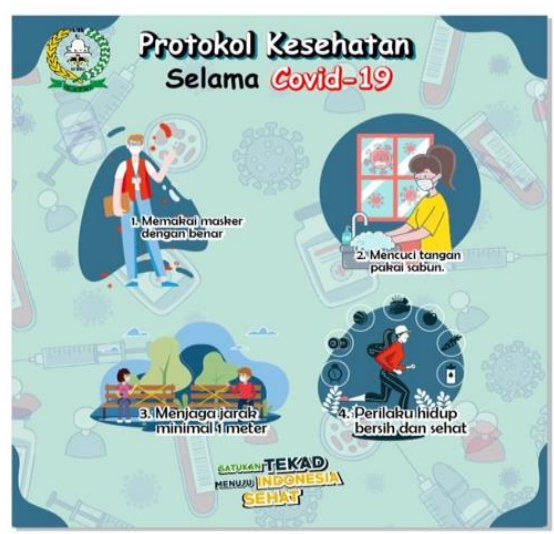

Gambar 2. Poster Protokol Kesehatan

\section{KESIMPULAN DAN SARAN}

\section{Kesimpulan}

Kegiatan ini dihadiri 17 peserta dan ketua RT 32 Kelurahan Lebak bandung 
Kota Jambi. Peserta mampu memahami cara menerapkan protokol kesehatan dimasa pandemic covid 19.

\section{Saran}

Saran bagi Kelurahan Lebak Bandung melakukan kerjasama dengan pihak Puskesmas untuk menyusun program kegiatan tindakan pencegahan penularan covid 19 dilingkungan sekitar.

\section{UCAPAN TERIMAKASIH}

Ucapan terimakasih kepada ketua RT 32 kelurahan Lebak Bandung yang telah menfasilitasi kegiatan ini sampai selesai dan Ketua Stikes Baiturahim yang telah mendanai kegiatan pengabdian ini dalam menunjang tri darma perguruan Tinggi.

\section{DAFTAR PUSTAKA}

Djalante, R., Lassa, J., Setiamarga, D., Sudjatma, A., Indrawan, M., Haryanto, B., Et Al. .2020.Review And Analysis of Current Responses To COVID-19 In Indonesia: Period Of January Until March 2020. Progress In Disaster Science 6, 1-9.

Gugus Tugas COVID 19, P. P. 2020. Badan Nasional Penanggulangan Bencana. Retrieved From Https://Bnpb.Go.Id: Https://Bnpb.Go.Id/Berita/PasienSembuh-Covid19-Menjadi-1-954Sebanyak-18-Provinsi-Tak-LaporkanKasus-Baru

Direktorat Jenderal Pencegahan Dan Pengendalian Penyakit, K. (2020). Pedoman Pencegahan Dan Pengendalian Coronavirus Disease (COVID-19). Jakarta Selatan: Direktorat Surveilans Dan Karantina Kesehatan Sub Direktorat Penyakit Infeksi Emerging

Fakultas Peternakan Universitas Andalas (2020) . Laporan kegiatan pengabdian masyarakat. Edukasi tentang protokol pencegahan covid-19 di masa kenormalan baru (new normal) dan distribusi hand sanitizer kepada masyarakat di lingkungan kecamatan koto tangah dan padang utara kota padang.

Keputusan Menteri Kesehatan Republik Indonesia Nomor

Hk.01.07/Menkes/382/2020

Tentang Protokol Kesehatan Bagi Masyarakat Di Tempat Dan Fasilitas Umum Dalam Rangka Pencegahan Dan Pengendalian Corona Virus Disease 2019 (Covid-19) 